\title{
The Effect of Suicide Prevention Education on Attitudes Toward Suicide in Police Officers
}

\author{
Yujin Ko, HyunChul Youn, Soyoung Irene Lee, Jeewon Lee, Areum Lee, and Shin-Gyeom Kim $\bowtie$ \\ Department of Psychiatry, Soonchunhyang University Bucheon Hospital, Bucheon, Republic of Korea
}

\begin{abstract}
Objective This study investigated the effect of suicide prevention education on attitudes toward suicide among police officers.
Methods We used an anonymous questionnaire for 518 officers and surveyed the demographic profiles and examined attitudes toward suicide utilizing the Attitudes Towards Suicide Scale (ATTS) (1=totally agree, $5=$ totally disagree). Our study divided participants into two groups, based on whether or not they had received suicide prevention education, and examined the differences in attitudes toward suicide between the groups.

Results Of the total population, 247 (47.7\%) officers had received suicide prevention education. The education group thought suicide as a predictable matter, disagreeing significantly more with the ATTS factor 'suicide is unpredictable' ( $3.36 \mathrm{vs.} 3.35 ; \mathrm{p}=0.001)$ compared with the no education group. Also, the education group more perceived suicide as a cry for help and at the same time disagreed more with the notion 'suicidal thoughts will never disappear' ( 2.08 vs. 2.26 ; $\mathrm{p}=0.025,3.2$ vs. $3.05 ; \mathrm{p}=0.035$, respectively).

Conclusion Officers with experience in suicide prevention education showed more positive attitude toward suicide and suicide prevention. These findings suggest a need to organize more opportunities of suicide prevention educations, such as making the training mandatory for police officers.

Psychiatry Investig 2021;18(11):1076-1081
\end{abstract}

Keywords Attitudes; Police; Suicide; Suicidal ideation; Suicide prevention education.

\section{INTRODUCTION}

Suicide is a public health challenge worldwide accounting for 11.2 deaths per 100,000 people every year. ${ }^{1}$ In South Korea, 26.6 people per 100,000 population died of suicide in 2018, recording almost the highest suicide rate among Organization for Economic Cooperation and Development (OECD) countries. ${ }^{1}$ As suicide is an important issue, many strategies are being studied for suicide prevention and many institutions are involved in the process. Police officers can also contribute to suicide prevention in several ways. Especially, the role of the police in recognizing and managing individuals at risk of suicide is becoming increasingly important. ${ }^{2}$ Police officers are in frequent contact with suicidal individuals because they are one of the first emer-

Received: May 25, 2021 Revised: August 14, 2021

Accepted: August 22, 2021

$\triangle$ Correspondence: Shin-Gyeom Kim, MD, PhD

Department of Psychiatry, Soonchunhyang University Bucheon Hospital, 170 Jomaru-ro, Bucheon 14584, Republic of Korea

Tel: +82-32-621-5063, Fax: +82-32-621-5750

E-mail: redmensch@schmc.ac.kr

(a) This is an Open Access article distributed under the terms of the Creative Commons Attribution Non-Commercial License (https://creativecommons.org/licenses/bync/4.0) which permits unrestricted non-commercial use, distribution, and reproduction in any medium, provided the original work is properly cited. gency services to be alerted when an individual is suspected of being at risk of suicide. ${ }^{3}$ According to a study in the UK, nearly a quarter of all subjects who died from suicide had encountered police officers during the three months prior to death. ${ }^{4}$ In addition, the police are also more directly involved in suicide prevention and management. In Korea, the police have the legal authority to directly request admission to a psychiatric ward to protect and treat patients at risk of suicide, and collaborate with mental health professionals. ${ }^{5}$ Also, since the government reinforced the suicide prevention policy from 2018, the police have focused on practicing suicide prevention policies by designating police officers specifically in charge of suicide and cracking down on the dissemination of suicide-related information on the internet. ${ }^{5}$

Attitudes toward suicide reflect a consistent view of suicide and an individual's persistent opinion on suicidal behavior. ${ }^{6} \mathrm{An}$ individual's attitude toward suicide can also affect especially those dealing with suicide-related tasks. According to one study, mental health workers, who consider suicide as a human right, have reported low levels of confidence when counseling suicide attempters. ${ }^{7}$ Suicide prevention training program has also been associated with better and more positive attitudes toward sui- 
cide in many studies. ${ }^{8-12}$ However, the studies were conducted mainly among health professionals and only few studies have focused on police officers. ${ }^{2.5} \mathrm{~A}$ previous study in the UK reported that police officers were more confident toward suicide prevention after the training; however, the results were based on a small sample size. ${ }^{2}$ A Korean study found that police officers who are educated in suicide prevention showed better perception regarding suicide, but the study population was heterogeneous and included individuals whose main job was not related to suicide or without direct contact with people at risk of suicide such as plain office workers. ${ }^{5}$

The perceptions and attitudes of the police officers to suicidal behavior can have an important influence on their view of suicidal patients and their suicide prevention related work. The aim of this study was to investigate how suicide prevention education affects the attitudes and perceptions toward suicide in police officers, especially those working in front-line. We hypothesized that the education program would have a positive effect on police officers, and through this, we tried to investigate the necessity of providing the program more to the police officers.

\section{METHODS}

\section{Subjects}

This study was based on an anonymous questionnaire survey that was administered to police officers working at local districts in Bucheon city, South Korea. Total 526 police officers from 14 districts participated in the survey and 8 questionnaires were excluded for not having completed suicide attitude scale. The remained 518 (98\%) questionnaires were suitable for analysis. The paper questionnaire with instructions was sent via postal mail or delivered by hand to each department. The officers were informed of the survey by trained instructors and informed consent was obtained for each participant. The inclusion period was from December 2020 to January 2021. The paper questionnaire was designed to be completed in 20 minutes. This study was approved by the Institutional Review Board (IRB) of Soonchunhyang University Bucheon Hospital (IRB No. 2020-09-016).

\section{Suicide Prevention Education}

The police participating in this study received the Korean Standard Suicide Prevention Education Program. It is not a mandatory course, and the officers usually decide whether or not to receive the education. ${ }^{5}$ The Korean Standard Suicide Prevention Education Program is for the general population and was a joint effort by the Korean Standard Suicide Prevention Education Program Development Committee comprising multidisciplinary experts set up by the Korea Suicide Prevention Association in 2012. ${ }^{13}$ In 2019, a total of 53,002 people com- pleted the educational program. ${ }^{14}$ The program is performed by qualified experts who are trained and officially authorized by Korea Suicide Prevention Center and the trainees receive a certificate after 3 hours of the program. The title of the program is 'observing, listening, and speaking', and the program focuses on teaching the gatekeeper's role through explaining the meaning of each word of the title: "Observing" emphasizes early detection of danger signs and offers potential warning signs. The "Listening" section provides training in active and sympathetic listening to people at risk of suicide. The last part, the "Speaking" section, contains safety checklist and referral system and collaboration with mental health professionals.

\section{Questionnaire}

Survey items of the questionnaire included basic demographic profiles such as sex, age, education level, marital status, residence status, religion, and duration of service as police officers. Also, the history of past suicidal ideation, attempts, and any major psychiatric problem were evaluated as well.

\section{Attitudes Toward Suicide Scale (ATTS)}

In order to explore the attitudes toward suicide, we used the revised Korean version of Attitudes Toward Suicide Scale-20 (ATTS-20) ${ }^{15}$ of the pre-existing questionnaire that had been developed by Renberg and Jacobsson (Supplementary Tables 1 and 2 in the online-only Data Supplement). ${ }^{16}$ Understanding the attitudes and perception toward suicide may be crucial in suicide prevention and intervention among individuals with suicidal tendencies. For this reason, many studies have vigorously developed scales to assess attitudes toward suicide and ATTS has been suggested as one of the most feasible and valid instruments for the general population. ${ }^{17}$ The ATTS is used to measure a broad dimension of suicidal attitudes including a right, preventability, taboo, communication and comprehensibility and consists of 37 items scored on a five-point Likert scale. ${ }^{18}$ The revised Korean versions of ATTS, called ATTS-20, consists of 20 items collected from the original ATTS and is a validated tool used in a national survey of suicide. ${ }^{15}$ Four-factor structures were found: ${ }^{15}$ Factor 1 "Suicide is acceptable" including items 1, 2, 3, 4, 11 and 15; Factor 2 "Suicide is preventable" comprising items 6, 8, 10, 13 and 14; Factor 3 "Suicide is common" with items 9, 16 and 18; and Factor 4 "Suicide is unpredictable" involving items 5, 7 and 19. The items 12,17 and 20 were not included in any factors. The items are scored on a five-point Likert scale ( $1=$ totally agree, $5=$ totally disagree).

\section{Statistical analysis}

All statistical analyzes were performed using SPSS 26.0 for Windows (IBM Corp., Armonk, NY, USA) and R software (v. 3.5.3; R Foundation for Statistical Computing, Vienna, Austria). 
The student's t-test was used for continuous variables, and the figures were presented as means with standard deviations. The categorical variables were presented as frequencies with percentages using the chi-square test. We divided total study population into two groups according to whether or not they had received suicide prevention education and compared demographic profiles between the groups. Then, we used analysis of covariance (ANCOVA), adjusting for sex, to compare the attitudes toward suicide between the groups. The level of significance was set at $\mathrm{p}<0.05$.

\section{RESULTS}

Table 1 shows the demographic profiles of the study population. The average age of the participants in this study was 36.89 years and 453 (87.96\%) subjects were male. The average working period was 117.95 months, and $81.27 \%$ (421 people) had experience in suicide-related work. Eight participants (1.54\%) had a history of psychiatric disorder, 64 (12.36\%) had suicidal ideation, and $5(0.97 \%)$ had previous suicide attempt. Among the total participants, 271 (52.32\%) received suicide prevention education. Comparison of characteristics between the two groups, education group vs. no education group, are also presented. No significant difference was found between the groups, except for sex. More descriptive data are provided in Table 1.

Table 2 shows the result of the comparison of ATTS scores between the two groups. To control the effect of sex, we performed ANCOVA between the two groups with sex as a covariate. The analysis revealed that the education group scored higher in factor 4 than the no-education group (3.32 vs. 3.17,

Table 1. General characteristics of the study population

\begin{tabular}{|c|c|c|c|c|}
\hline & Total $(\mathrm{N}=518)$ & No education $(\mathrm{N}=247)$ & Education $(\mathrm{N}=271)$ & $\mathrm{p}$-value \\
\hline Age, years & $36.89 \pm 8.05$ & $36.3 \pm 7.74$ & $37.44 \pm 8.3$ & 0.105 \\
\hline Sex, $N$ & & & & 0.004 \\
\hline Male & $453(87.96)$ & $206(83.4)$ & $247(92.16)$ & \\
\hline Female & $62(12.04)$ & $41(16.6)$ & $21(7.84)$ & \\
\hline Education level, years & $14.77 \pm 1.73$ & $14.67 \pm 1.64$ & $14.86 \pm 1.81$ & 0.216 \\
\hline Marital status, $\mathrm{N}$ & & & & 0.876 \\
\hline Single & $217(41.89)$ & $108(43.72)$ & $109(40.22)$ & \\
\hline Married & $295(56.95)$ & $136(55.06)$ & $159(58.67)$ & \\
\hline Living together without marriage & $4(0.77)$ & $2(0.81)$ & $2(0.74)$ & \\
\hline Divorced & $0(0)$ & $0(0)$ & $0(0)$ & \\
\hline Separated by death & $2(0.39)$ & $1(0.4)$ & $1(0.37)$ & \\
\hline Residence status & & & & 0.421 \\
\hline Living alone & $106(20.5)$ & $54(21.86)$ & $52(19.26)$ & \\
\hline Living with family members including spouse & $295(57.06)$ & $136(55.06)$ & $159(58.89)$ & \\
\hline Living with family members other than spouse & $114(22.05)$ & $57(23.08)$ & $57(21.11)$ & \\
\hline Living with a partner other than the family & $2(0.39)$ & $0(0)$ & $2(0.74)$ & \\
\hline Religion & & & & 0.313 \\
\hline None & $377(73.06)$ & $178(72.65)$ & $199(73.43)$ & \\
\hline Christian & $66(12.79)$ & $37(15.1)$ & $29(10.7)$ & \\
\hline Buddhism & $42(8.14)$ & $16(6.53)$ & $26(9.59)$ & \\
\hline Catholicism & $30(5.81)$ & $13(5.31)$ & $17(6.27)$ & \\
\hline Other & $1(0.19)$ & $1(0.41)$ & $0(0)$ & \\
\hline Employment period, months & $117.95 \pm 115.42$ & $110.39 \pm 106.15$ & $125.01 \pm 123.24$ & 0.156 \\
\hline \multicolumn{5}{|l|}{ History of } \\
\hline Psychiatric disorder, $\mathrm{N}$ & $8(1.54)$ & $2(0.81)$ & $6(2.21)$ & 0.348 \\
\hline Suicidal ideation, $\mathrm{N}$ & $64(12.36)$ & $31(12.55)$ & $33(12.18)$ & $>0.999$ \\
\hline Suicide attempts, $\mathrm{N}$ & $5(0.97)$ & $2(0.81)$ & $3(1.11)$ & $>0.999$ \\
\hline Experience in suicide-related work & $421(81.27)$ & $198(80.16)$ & $223(82.29)$ & 0.612 \\
\hline
\end{tabular}

Numeric parameters are expressed as mean \pm standard deviation, and categorical variables are expressed as counts and percentages in parentheses 
Table 2. Comparison of ATTS score based on suicide prevention education

\begin{tabular}{lccc}
\hline & No education $(\mathrm{N}=247)$ & Education $(\mathrm{N}=271)$ & \\
\hline Outcomes & & $3.52 \pm 0.72$ & Adjusted $\mathrm{p}$ \\
Factor 1: suicide is acceptable & $3.47 \pm 0.7$ & $2.67 \pm 0.54$ & 0.073 \\
Factor 2: suicide is preventable & $2.65 \pm 0.63$ & $2.95 \pm 0.56$ & 0.138 \\
Factor 3: suicide is common & $3.02 \pm 0.62$ & $3.32 \pm 0.62$ & 0.691 \\
Factor 4: suicide is unpredictable & $3.17 \pm 0.66$ & & 0.001 \\
Single items & & $2.08 \pm 0.88$ & 0.025 \\
12. Suicide is a cry for help & $2.26 \pm 0.89$ & $3.45 \pm 0.78$ & 0.146 \\
17. Attempts due to revenge and punishment & $3.38 \pm 0.82$ & $3.2 \pm 0.98$ & 0.034 \\
20. Suicidal thoughts will never disappear & $3.05 \pm 0.98$ & & \\
\hline
\end{tabular}

Numeric parameters are expressed as mean. ATTS, Attitudes Towards Suicide Scale

$\mathrm{p}=0.001$ ), meaning the education group disagreed more with 'suicide is unpredictable.' As for the single items, the education group agreed significantly more with item 12 : 'suicide is a cry for help' (2.08 vs. $2.26 \mathrm{p}=0.025)$ and disagreed more with item 20: 'suicidal thoughts will never disappear' ( 3.2 vs. $3.05 \mathrm{p}=0.034$ ) than the no-education group. No statistically significant difference was found between factors 1,2 , and 3 .

\section{DISCUSSION}

In this study based on an anonymous questionnaire survey of police officers, we investigated 518 officers working in local districts and found an association between positive attitude towards suicide prevention and experience in suicide prevention training program. The police who were trained with the program reported to further disagree with the notion "suicide is unpredictable" than those who were not trained. The Korean standard suicide prevention education program that the officers generally receive explains the importance of early detection of the people at risk of suicide as one of gatekeepers' roles and provides useful information about detecting danger signals. ${ }^{13}$ As a consequence, the trained police officers may have learned ways to identify risks before suicide attempts. A previous study investigating the effect of the same program also showed that individuals who were trained with the program were reported to well recognize that those at high risk of suicide generally send complicated signals implying suicide. ${ }^{13}$ Also, those who had received the education agreed more strongly with 'suicide is a cry for help' than those who had not received the education, showing they perceive suicide more as a critical topic and that suicidal people require assistance. At the same time, the trained officers disagreed significantly with the idea 'suicidal thoughts will never disappear' and this may reflect the officers' hope and anticipation that suicidal thoughts might disappear if appropriate intervention is accompanied. These attitudes may be helpful for the gatekeeper's roles suggested in suicide prevention education, such as detecting danger signals and referring those in need to proper services. ${ }^{13}$

As for the other factors, there are some notable points to consider although no significant difference was found between two groups. All the participants tended to disagree with the statement that "suicide is acceptable" and agree that "suicide is preventable." These results may be attributed to the unique characteristics of the study population. Given that the officers participating in this study worked in the forefront of service, the participants may have experienced emergencies in practice. In Korea, it is one of the police responsibilities to identify online articles implying the risk of suicide, such as Social Networking Service (SNS) articles confessing plans for suicide attempt, and read individual stories in detail, which reveals the person's circumstances. ${ }^{19}$ Such experience may have influenced the participants to perceive suicide as a critical topic and that suicidal people require assistance. Furthermore, as the number of suicide-related tasks in the police has increased along with the role of police involvement in suicide events, ${ }^{20}$ the likelihood of understanding the severity of suicide may have increased. However, factor 3 ("suicide is common") was not supported or denied by most of the participants who were not sure, and no difference was found according to the experience in suicide prevention education. Participants tended to only mildly agree with the items such as 'anyone can commit suicide', with similar levels of awareness among the trained participants. This may be because the police officers were mainly responsible for dispatching in response to emergency calls, not the overall suicide management. In addition, the police usually act according to the law and focus more on the cases that need judicial intervention. ${ }^{21}$ Therefore, police officers usually cover specific areas of suicide management and are less frequently involved in the overall process. Although current suicide prevention education allows officers to detect danger signals better, an understanding of the universality of suicide is also needed for enhanced screening and detection of people at risk of suicide. 
Our finding is consistent with previous reports in that suicide prevention education is related to positive and confident attitudes among police officers. ${ }^{2,5} \mathrm{~A}$ previous study in Korea also reported that suicide prevention education was associated with attitudes toward suicide among male police officers. ${ }^{5}$ The study analyzed the participant's attitudes toward suicide based on 6 items including 'suicide is a cry for help' and 'suicide is preventable' extracted from ATTS and reported that the sum of the 6 items was higher among officers who had received suicide prevention education, suggesting that the overall attitude and perception toward suicide is associated with education experience. A British study examined the impact of their training program on attitudes toward suicide prevention by comparing the attitude of the officers before, immediately after, and 6 months after the training with a brief questionnaire, ${ }^{2}$ the participants scored significantly higher after the training on items such as 'I feel I can accurately identify situations where a person is at risk of suicide, indicating increased confidence after the training that was maintained over 6 months.

The results of this study confirm the important role played by police officers in suicide prevention and that suicide prevention education is associated with positive attitudes toward suicide and suicide prevention. The study participants were frontline officers who worked in duty related with individuals at risk of suicide. We found the police officers who had received the education program more perceived suicide as a signal for help, thought suicide could be predicted, and that suicidal thoughts had room for treatment, than the officers who had not received the program. These attitudes are in line with the contents of current suicide prevention education and support the positive effect of the education. However, the current suicide prevention education of police officers is merely a component of the normal curriculum after their appointment and not a major educational topic. Thus, it has been suggested that suicide prevention education should be strengthened as a policy intervention for the police. ${ }^{5}$ Suicide prevention education is only optional and is not included in the mandatory training program. In our study, only about half (271 people, 52.32\%) underwent suicide prevention training program. Our findings suggest the need for further suicide prevention training for police officers and police officers should be encouraged to participate in the education.

The strength of this study lies in that it investigated attitudes toward suicide in police officers, especially those working in fore-front of community suicide prevention. To the best of our knowledge, this is the first report to investigate the effect of current suicide prevention education on attitudes toward suicide among police officers in South Korea. Also, this study separates itself from a previous study conducted on Korean police officers in that our study population included both sexes.

There are several limitations to consider regarding the above findings. First, as this was a cross-sectional study, the change before and after the education program or the causal relationship was not investigated. Second, there is a possibility that individuals with more interest in suicide or suicide prevention may have participated voluntarily in the education program and selection bias may have occurred. Third, there was no control group, and we did not compare the officers with others. Comparing the officers with the control group may facilitate the identification of police-specific characteristics. Fourth, although we have selected one of the existing factor models for the ATTS, various factor models exist, and results and interpretations may vary accordingly. It would have been more helpful in examining the attitudes toward suicide among police officers if we had conducted analysis on the factor model. Finally, though matching was done to avoid sex differences, the baseline total population consisted mainly of male police officers, which limits generalization of the results to the female police population. Female police officers account for $12.7 \%$ of all police officers in Korea, ${ }^{22}$ and the distribution of the study population in this study was similar. However, the number of female officers is increasing, not only globally but also in Korea ${ }^{22-24}$ and their roles in policing have progressed to the same extent as those of male officers. ${ }^{24}$ Therefore, a well-organized and larger study consisting of female officers is needed to better represent the police population.

The police play a primary role in the prevention of suicide and the management of patients with suicidal tendencies. This study investigated the effect of suicide prevention education on police attitudes toward suicide. The data indicated that the officers who received the education program showed more positive attitude toward suicide and suicide prevention, while the education completion rate was reported to be low. Accordingly, it may be important for police officers, especially those engaged in front-line duty to identify persons at risk of suicide, to receive suicide prevention education. Thus, approaches such as participation in suicide prevention education as a mandatory course might be helpful.

\section{Supplementary Materials}

The online-only Data Supplement is available with this article at https://doi.org/10.30773/pi.2021.0176.

\section{Availability of Data and Material}

The datasets generated or analyzed during the study are available from the corresponding author on reasonable request.

\section{Conflicts of Interest}

The authors have no potential conflicts of interest to disclose.

\section{Author Contributions}

Conceptualization: Shin-Gyeom Kim. Data curation: Yujin Ko. Formal analysis: Yujin Ko. Funding acquisition: Shin-Gyeom Kim. Investigation: 
Yujin Ko. Methodology: Yujin Ko, Jeewon Lee, HyunChul Youn. Project administration: Soyoung Irene Lee, Shin-Gyeom Kim. Supervision: ShinGyeom Kim. Validation: Soyoung Irene Lee, Jeewon Lee, HyunChul Youn. Visualization: Yujin Ko. Writing—original draft: Yujin Ko. Writing-review \& editing: all authors.

\section{ORCID iDs}

Yujin Ko https://orcid.org/0000-0003-4201-9343

HyunChul Youn https://orcid.org/0000-0002-6557-5628

Soyoung Irene Lee https://orcid.org/0000-0003-2473-2954

Jeewon Lee https://orcid.org/0000-0001-5930-1834

Areum Lee https://orcid.org/0000-0001-6931-8488

Shin-Gyeom Kim https://orcid.org/0000-0001-8196-655X

\section{Funding Statement}

This study was supported by the Soonchunhyang Research Fund.

\section{REFERENCES}

1. Korea S. Annual Report on the Cause of Death Statistics. Daejeon: Statistics Korea; 2019.

2. Marzano L, Smith M, Long M, Kisby C, Hawton K. Police and suicide prevention. Crisis 2016;37:194-204.

3. Matheson FI, Creatore MI, Gozdyra P, Moineddin R, Rourke SB, Glazier RH. Assessment of police calls for suicidal behavior in a concentrated urban setting. Psychiatr Serv 2005;56:1606-1609.

4. Linsley KR, Johnson N, Martin J. Police contact within 3 months of suicide and associated health service contact. Br J Psychiatry 2007;190: 170-171.

5. Choi EJ, Cho JH, Jeong GC, Kim AS. A study on male police officers' perception of suicide prevention. Korean Assoc Police Sci Rev 2020; 22:307-337.

6. Domino G, Takahashi Y. Attitudes toward suicide in Japanese and American medical students. Suicide Life Threat Behav 1991;21:345359.

7. Neimeyer RA, Fortner B, Melby D. Personal and professional factors and suicide intervention skills. Suicide Life Threat Behav 2001;31:71-82.

8. Kodaka M, Inagaki M, Yamada M. Factors associated with attitudes toward suicide. Crisis 2013;34:1-8.

9. Chan SW, Chien WT, Tso S. Evaluating nurses' knowledge, attitude and competency after an education programme on suicide prevention. Nurse Educ Today 2009;29:763-769.

10. Berlim MT, Perizzolo J, Lejderman F, Fleck MP, Joiner TE. Does a brief training on suicide prevention among general hospital personnel im- pact their baseline attitudes towards suicidal behavior? J Affect Disord 2007;100:233-239.

11. McAuliffe C, Corcoran P, Keeley HS, Perry IJ. Risk of suicide ideation associated with problem-solving ability and attitudes toward suicidal behavior in university students. Crisis 2003;24:160-167.

12. Terpstra S, Beekman A, Abbing J, Jaken S, Steendam M, Gilissen R. Suicide prevention gatekeeper training in the Netherlands improves gatekeepers' knowledge of suicide prevention and their confidence to discuss suicidality, an observational study. BMC Public Health 2018; 18:637.

13. Paik JW, Jo SJ, Lee S, Ong JY, Park JI. The effect of Korean Standardized Suicide Prevention Program on Intervention by gatekeepers. J Korean Neuropsychiatr Assoc 2014;53:358-363.

14. Korea Suicide Prevention Center. Statistics on the number of trainees of the suicide prevention education. Available at: http://jikimi.spckorea.or.kr/new/data/data03.php. Accessed April 10, 2021.

15. Park JI, Kim YJ. Factor Structure of Korean Version of Attitudes Toward Suicide (ATTS-20). Ment Health and Soc Work 2014;42:91-113.

16. Renberg ES, Jacobsson L. Development of a questionnaire on attitudes towards suicide (ATTS) and its application in a Swedish population. Suicide Life Threat Behav 2003;33:52-64.

17. Kodaka M, Poštuvan V, Inagaki M, Yamada M. A systematic review of scales that measure attitudes toward suicide. Int J Soc Psychiatry 2011; 57:338-361.

18. Norheim AB, Grimholt TK, Loskutova E, Ekeberg O. Attitudes toward suicidal behaviour among professionals at mental health outpatient clinics in Stavropol, Russia and Oslo, Norway. BMC Psychiatry 2016; $16: 268$

19. Kim JO, Lee DS. A study on the rate of suicide and the countermeasures of policing activity. Korean J Public Safety Crim Justice 2009;18: 59-89.

20. Jeong LM. A study on demand trend and active measures of police suicide crisis intervention in Korea. J Police Sci 2015;15:3-26.

21. Park S. Study on the appropriate response by the police to the failed suicide attempt. Chosun Law J 2011;18:347-375.

22. Ministry of Sex Equality and Family. Statistics on the number of female government employees. Available at: http://www.mogef.go.kr/ nw/enw/nw_enw_s001d.do?mid=mda700. Accessed April 10, 2021.

23. Hyland SS, Davis E. Local Police Departments, 2016: Personnel. Las Vegas: United States Department of Justice Office of Justice Programs Bureau of Justice Statistics; 2019.

24. Rabe-Hemp CE. The Status of women Police Across the Globe. Women Policing across the Globe: Shared Challenges and Successes in the Integration of Women Police Worldwide 2019: 3. 


\begin{tabular}{|c|c|c|c|c|}
\hline $\begin{array}{l}\text { 매우 } \\
\text { 동의함 }\end{array}$ & 동의함 & $\begin{array}{c}\text { 잘 } \\
\text { 모르 겠음 }\end{array}$ & $\begin{array}{c}\text { 동의하지 } \\
\text { 않음 }\end{array}$ & $\begin{array}{l}\text { 매우 동의 } \\
\text { 하지 않음 }\end{array}$ \\
\hline
\end{tabular}

1. 사람들은 자신의 생명을 스스로 끊을 권리가 있다.

2. 자살만이 유일한 합리적 해결책인 상황이 있다.

3. 누군가 자살을 원한다면 그 사람의 일이므로 우리가 간섭하지 말아야 한다.

4. 자살은 불치병을 마감하기 위한 합당한 수단이다.

5. 자살은 아무런 경고 없이 발생한다.

6. 누군가 자살에 대하여 생각하고 있음에도 불구하고 가족들은 대개 무 슨 일이 진행되고 있는지를 알지 못한다.

7. 자살하는 사람들은 대개 정신질환을 갖고 있다.

8. 젊은이들의 자살은 아직 삶의 가능성이 무한하기 때문에 특히 이해할 수 없다.

9. 누구든지 자살할 수 있다.

10. 자살에 대하여 이야기하는 사람들이 반드시 자살을 하는 것은 아니다.

11. 자살한다고 위협하는 사람들이 실제로 자살을 하는 경우는 드물다.

12. 자살시도는 기본적으로 도움을 요청하는 신호이다.

13. 누군가의 자살을 막기 위해 애쓰는 것은 인간의 의무다.

14. 자살생각을 가진 사람을 돕는 것은 항상 가능하다.

15. 누군가 자살하겠다는 결심을 한다면 아무도 그 사람을 막을 수 없다.

16. 대부분의 자살시도는 친한 사람과의 갈등 때문이다.

17. 누군가에게 복수하거나 처벌하려고 자살시도를 하는 경우가 많다.

18. 누군가 자살한다면 오랜 시간 동안 심사숙고한 결과이다.

19. 대부분의 자살시도는 충동적인 행동이다.

20. 자살을 한 번 생각했던 사람은 절대로 그 생각을 버리지 못한다. 


\begin{tabular}{|c|c|c|c|c|}
\hline $\begin{array}{l}\text { Totally } \\
\text { agree }\end{array}$ & Agree & Neutral & Disagree & $\begin{array}{c}\text { Totally } \\
\text { disagree }\end{array}$ \\
\hline
\end{tabular}

1. People have the right to take their own lives

2. There may be situations where the only reasonable resolution is suicide

3. If someone wants to commit suicide it is their business and we should not interfere

4. Suicide is an acceptable means to terminate an incurable disease

5. Suicide happens without warning

6. Relatives usually have no idea about what is going on when a person is thinking about suicide

7. People who commit suicide are usually mentally ill

8. Suicides among younger people are particularly puzzling because they have everything to live for

9. Anybody can commit suicide

10. People who talk about suicide do not necessarily commit suicide

11. Whoever keeps threatening usually does not kill himself/herself

12. Suicide is a cry for help

13. It is a human duty to try to stop someone from committing suicide

14. It is always possible to help a person with suicidal thoughts

15. Once a person has made up his/her mind about committing suicide, no one can stop him/her

16. Most suicide attempts are caused by conflicts with a close person

17. Many suicide attempts are made because of revenge or to punish someone else

18. When a person commits suicide, it is something that he/she has considered for a long time

19. Most suicide attempts are impulsive actions

20. A person once they have suicidal thoughts will never let them go 